\title{
RDUS
}

Revue de DROIT UNIVERSITÉ DE SHERBROOKE

Titre : $\quad$ CROWNING GLORY : LIABILITY IN NEGLIGENCE OF PUBLIC AUTHORITIES REVISITED

Auteur(s) : $\quad$ Peter BOWAL, Lynn BOLAND

Revue : $\quad$ RDUS, 1993-1994, volume 24, numéro 2

Pages: $\quad 435-459$

ISSN : $\quad 0317-9656$

Éditeur : $\quad$ Université de Sherbrooke. Faculté de droit.

URI : $\quad$ http://hdl.handle.net/11143/13376

DOI : https://doi.org/10.17118/11143/13376 
Page vide laissée intentionnellement. 


\title{
COMMENTAIRE
}

\section{CROWNING GLORY : LIABILITY IN NEGLIGENCE OF PUBLIC AUTHORITIES REVISITED}

\author{
by Peter BOWAL* \\ Lynn BOLAND**
}

Cet article retrace les développements du droit qui ont permis qu'un recours pour négligence puisse être intenté contre la Couronne. La décision de la Chambre des Lords dans l'affaire Anns a laissé aux canadiens un héritage durable. Elle oblige à distinguer selon que la sphère de gouvernement en question est politique (non sujette à révision) ou fonctionnelle (révisable). Mais ce modèle est néanmoins peu pratique et ne comprend aucun critère d'application uniforme. La Cour Suprême du Canada eut récemment l'occasion, dans l'affaire Brown puis l'affaire Swinamer, d'établir une approche plus efficace au problème de la responsabilité des autorités publiques pour négligence, mais s'est abstenue de le faire. Les auteurs suggèrent que ces deux affaires ne font que confirmer la politique judiciaire canadienne actuelle de respecter la voie tracée par l'affaire Anns, et ce malgré ses faiblesses inhérentes et les incertitudes qui en découlent.

This article traces the development of the law which gradually permitted negligence actions to be brought against the Crown. The House of Lords decision in Anns has had a durable legacy in Canada. It calls for characterizing the sphere of government activity in question as either political (not reviewable) or operational (reviewable). The model is, nevertheless, unwieldy and lacks standards for predictable application. The Supreme Court of Canada had occasion recently in the cases of Brown and Swinamer to craft a more effective approach to the issue of negligence liability for public authorities, but failed to do so. The authors submit that these two cases merely affirm Canadian judicial policy to stay the Anns course for now, notwithstanding the attendant weaknesses and uncertainties of it.

*. Associate Professor, Faculty of Management, University of Calgary.

**. MBA Candidate, Faculty of Management, University of Calgary. 
TABLE OF CONTENTS

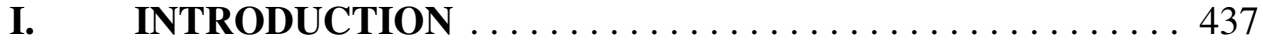

II. BACKGROUND TO THE DOCTRINE $\ldots \ldots \ldots \ldots \ldots \ldots 48$

III. RECENT CANADIAN APPLICATIONS OF ANNS . . . . 442

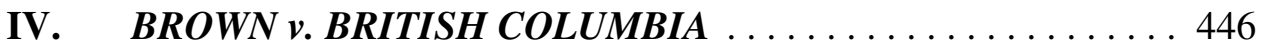

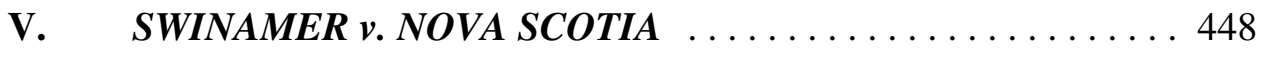

VI. ANALYSIS AND CONCLUSION $\ldots \ldots \ldots \ldots \ldots \ldots \ldots 3$ 
Better that an individual should suffer an injury

than that the public should suffer an inconvenience.

\section{Russell v. The Mayor of Devon ${ }^{1}$}

\section{INTRODUCTION}

The Supreme Court of Canada recently issued contemporaneous judgments in two cases involving claims of negligence on the part of public authorities. The court again applied the «policy» versus «operations» decisionmaking model to determine liability. These principles, originally laid out in Anns v. Merton London Borough Council ${ }^{2}$, were relied upon in decisions such as Barratt v. North Vancouver ${ }^{3}$, City of Kamloops v. Nielsen ${ }^{4}$ and were more recently expounded upon in Just v. British Columbia ${ }^{5}$. These two new cases, Brown v. British Columbia (Minister of Transportation) ${ }^{6}$ and Swinamerv. Nova Scotia (Attorney General) ${ }^{7}$, are important in how they demonstrate the court's steadfast adherence to this approach to negligence of public authorities.

1. (1788), 1 T.R. 673, per Justice Ashhurst.

2. [1978] A.C. 728, [1977] 2 All E.R. 492 [hereinafter Anns].

3. [1980] 2. S.C.R. 418, (1980), 114 D.L.R. (3d) 577, 14 C.C.L.T. 169, 13 M.P.L.R. 116, 8 M.V.R. 294, 27 B.C.L.R. 182, 33 N.R. 293, 5 A.C.W.S. (2d) 259 [hereinafter Barratt].

4. [1984] 2 S.C.R. 2, (1984), 10 D.L.R. (4th) 641, 29 C.C.L.T. 97, 26 M.P.L.R. 81, [1984] 5 W.W.R. 1, 66 B.C.L.R. 273, 54 N.R. 1, 26 A.C.W.S. (2d) 453 [hereinafter Kamloops].

5. [1989] 2 S.C.R. 1228, 103 N.R. 1, 64 D.L.R. (4th) 689, 41 Admin. L.R. 161, 1 C.C.L.T. (2d) 1, [1989] I.L.R. $\llbracket 993,042,18$ M.V.R. (2d) 1, [1990] 1 W.W.R. 385, 41 B.C.L.R. (2d) 350, 18 A.C.W.S. (3d) 527 [hereinafter Just] (cited to S.C.R.).

6. [1994] 1 S.C.R. 420, (1994), 112 D.L.R. (4th) 1, [1994] 4 W.W.R. 194, 89 B.C.L.R. 1, 46 A.C.W.S. (3d) 797 [hereinafter Brown] (cited to D.L.R.).

7. [1994] 1 S.C.R. 445, (1994), 163 N.R. 291, 112 D.L.R. (4th) 18, 46 A.C.W.S. (3d) 798 [hereinafter Swinamer] (cited to D.L.R.). 


\section{BACKGROUND TO THE DOCTRINE}

The question of the liability of public authorities for their decisions and actions has its roots in the principles of Crown immunity. While it had long been held that the Crown was immune from tortious claims, there has been a gradual erosion of this immunity such that the Crown is increasingly liable for its actions ${ }^{8}$.

The Canadian Crown Liability Act ${ }^{9}$ was passed in 1951 following the enactment of the United Kingdom statute four years earlier which had provided for general tortious liability of the Crown. Until that time, the Crown suffered no legal liability ${ }^{10}$. However, public dissatisfaction with an inability to find anyone liable to plaintiffs who had endured injury at the hands of the Crown incited reform. In Canada between 1951 and 1974 nine of the provincial

8. For an overview of the evolution of liability of public authorities, see : L.A. REYNOLDS and D.A. HICKS, «New Directions for the Civil Liability of Public Authorities in Canada», (1992) 71 Can. Bar Rev. 1, and Paul M. PERELL, «Negligence Claims Against Public Authorities», (1994) 16 Advocates' Q. 48.

9. Now the Crown Liability and Proceedings Act, R.S.C 1985, c. C-50, as amended by S.C. 1990, c. 8.

10. East Suffolk Rivers Catchment Board v. Kent [1941] A.C. 74, [1940] 4 All E.R. 527 (H.L.). The plaintiffs' land was damaged as a result of flooding created by high spring tides and strong winds. The municipality undertook to repair the river bank by the authority granted in the Land Drainage Act, 1930 which included [at 529] «...the power to repair any existing watercourse or drainage work». In setting out the facts of the case, the House of Lords agreed with the lower courts [at 530]: «...that the methods adopted and the staff employed in trying to repair the damage to the wall with which we are concerned in this case were so inefficient that, whereas the gap could, by the exercise of reasonable skill, have been closed and the flooding arresting in 14 days, this result was not in fact attained till after the lapse of 164 days.»

Despite the official incompetence, however, the Board's conduct was held to be within the limits of statutory discretion. The House of Lords found that a municipality was immune when it had a discretionary authority to act provided by statute - even when there was a failure to act. Liability could only be founded where the municipal body acted out of a statutory duty. Accordingly, the plaintiffs' claim for damages was dismissed. Viscount Simon L.C. in the majority decision refers to the dissent of du Parcq L.J. from the Court of Appeal [at 532 and 544] : «du Parcq, L.J., in his dissenting judgment, points out that, when Parliament has left it to a public authority to decide which of its powers it shall exercise, and when and to what extent it shall exercise them, this may raise [p. 184] : ...a question involving the consideration of matters of policy and sometimes the striking of a just balance between the rival claims of efficiency and thrift.» 
jurisdictions ${ }^{11}$ passed legislation based on the British model. The changes typically stated that the Crown would be liable in tort as if it were «...a private person of full age and capacity» ${ }^{12}$. Even today, actionable negligence of the Crown continues to represent an important public policy. The Ontario Law Reform Commission has said that ${ }^{13}$ :

«... the most important head of tortious liability of the Crown, and ordinary negligence principles apply to the Crown as to any other person.»

The origins of the policy and operations distinction for Crown liability is found in forty year old American jurisprudence which sought to only partially, and rationally, open the door to suits of negligence against the state. The United States Supreme Court in Dalehite v. United States ${ }^{14}$ found that the «planning» decision to export dangerous fertilizer did not give rise to liability for the subsequent port explosion. The court stated it this way ${ }^{15}$ :

«In short, the alleged "negligence" does not subject the Government to liability. The decisions held culpable were all responsibly made at a planning rather than operational level and involved considerations

11. Quebec resisted the reform occurring throughout Canada because of its view that liability existed at common law by virtue of The King v. Cliche [1935] S.C.R. 561. Moreover, Article 1011 of the Code of Civil Procedure provided that «any person having a claim to exercise against the Government of this Province...[could] address a petition of right to Her Majesty».

12. See : Alberta : Proceedings Against the Crown Act, R.S.A. 1980, c. P-18; British Columbia : Crown Proceedings Act, R.S.B.C. 1979, c. 86; Manitoba : Proceedings Against the Crown Act, R.S.M. 1987, c. P-140; New Brunswick : Proceedings Against the Crown Act, R.S.N.B. 1973, c. P-18; Newfoundland : Proceedings Against the Crown Act, S.N. 1973, c. 59; Nova Scotia : Proceedings Against the Crown Act, R.S.N.S. 1989, c. 360; Ontario: Proceedings Against the Crown Act, R.S.O. 1980, c. 393; Prince Edward Island : Crown Proceedings Act, R.S.P.E.I. 1988, c. C-32; Saskatchewan : Proceedings Against the Crown Act, R.S.S. 1978, c. P-27.

13. The Ontario Law Reform Commission, Report on The Liability of the Crown (1989) at p. 12 .

14. 346 U.S. 15 (1953). The terminology used was «planning» versus «policy», but the meaning is the same. See, the Ontario Law Reform Commission, ibid: However, the liability of the Crown in negligence is limited by a distinction drawn by the courts between the planning level of government and the operational level of government.

15. Ibid., at 42 . 
more or less important to the practicability of the Government's fertilizer program.»

Similarly, Indian Towing Co. v. United States ${ }^{16}$ adopted the distinction. In that case the owners of a tug and barge, which had run aground due to a burnt out warning light in the lighthouse, alleged negligence on the part of the Coast Guard. The Supreme Court held that ${ }^{17}$ :

«The Coast Guard need not undertake the lighthouse service. But once it exercised its discretion to operate a light on Chandeleur Island and engendered reliance on the guidance afforded by the light, it was obligated to use due care to make certain that the light was kept in good working order; and, if the light did become extinguished, then the Coast guard was further obligated to use due care to discover this fact and to repair the light or give warning that it was not functioning. If the Coast Guard failed in its duty and damage was thereby caused to petitioners, the United States is liable...»

The Coast Guard had failed in the operational aspect of its duties to inspect the lighthouse and was liable to the owner of the ship who had suffered financial loss.

The arrival of this approach on Canadian shores began with Welbridge Holdings Ltd. v. Metropolitan Corp. of Greater Winnipeg ${ }^{18}$, in which the Supreme Court of Canada ruled that even where a municipality acts incorrectly, the exercise of that discretion at the policy level renders it immune and not subject to any private law duty of care. In that case, a municipal corporation revoked a building permit because it had itself failed to advise opponents to the development project of the re-zoning of the affected property. The developer brought suit against the municipality for damages for negligence. Laskin J., as he then was, held that where a municipality errs while exercising its «legislative capacity» or its «quasi-judicial duty», it is immune from civil liability, even

16. (1955) 350 U.S. 61, 76 S. Ct. 122 (cited to U.S.).

17. Ibid., at 69 .

18. [1971] S.C.R. 957, [1972] 3 W.W.R. 433, 22 D.L.R. (3d) 470. 
though it acts improperly. No duty of care is owed in such circumstances ${ }^{19}$.

This principle was entrenched with the House of Lords decision in Anns. There the plaintiffs were lessees of a building which showed signs of structural damage when the walls started to crack and the floors began to slope. They asserted that the building had been built on foundations that were not in accordance with the plans which had been deposited with the Council as required by the by-laws. These foundations were only to a depth of two feet six inches, instead of three feet or deeper as shown on the plans. The plaintiffs alleged that the municipality was liable for the damage because the building inspector had either carried out the inspection negligently or was negligent if no inspection had taken place.

Lord Wilberforce, for the majority, mused that there ought to be a distinction between «operational» areas and «policy» areas and that it was only the latter which should provide immunity for public authorities from claims of negligence. In order to establish if a duty of care was owed, two questions were presented $^{20}$ :

«First one has to ask whether, as between the alleged wrongdoer and the person who has suffered damage, there is a sufficient relationship of proximity or neighbourhood such that, in the reasonable contemplation of the former, carelessness on his part may be likely to cause damage to the latter - in which case a prima facie duty of care arises. Secondly, if the first question is answered affirmatively, it is necessary to consider whether there are any considerations which ought to negative, or to reduce or limit the scope of the duty or class of person to whom it is owed or the damages to which a breach of it may give rise...»

Lord Wilberforce concluded ${ }^{21}$ :

«... (3) that the council would not be guilty of a breach of duty in not

19. «Legislative» or «quasi-judicial» came to mean «policy» decisions : P. HOGG, Liability of the Crown, 2nd ed., Toronto, Carswell, 1989, at 124.

20. Ibid., at 968-70 (S.C.R.), 751-752 (A.C.), 498 (All E.R.).

21. Ibid., at 505-06 (All E.R.). 
carrying out inspection of the foundations of the block unless it were shown (a) not properly to have exercised its discretion as to the making of inspections, and (b) to have failed to exercise reasonable care in its acts or omissions to secure that the byelaws' application to the foundations of the block were complied with; (4) that the council would be liable to the plaintiffs for breach of duty if it were proved that its inspector having assumed the duty of inspecting the foundations, and acting otherwise than in the bona fide exercise of any discretion under the Act, did not exercise reasonable care to ensure that the byelaws applicable to the foundations were complied with...»

The court dismissed the appeal. The council had owed a private duty of care.

\section{RECENT CANADIAN APPLICATIONS OF ANNS}

Throughout the 1980's, cases such as Barratt ${ }^{22}$, Kamloops ${ }^{23}$ and Laurentide Motels v. City of Beauport ${ }^{24}$ were faithful to Anns when determining the liability of public authorities. By 1989, the decision rendered in Just ${ }^{25}$ attempted a development in this area of the law, but one might ask how, if at all, the law was clarified by it.

In Just, the plaintiff and his daughter were driving on the highway to Whistler Mountain in British Columbia for a day of skiing in January, 1982. A

22. Supra, note 3.

23. Supra, note 4. Wilson J. applied the principle in Anns to the facts in Kamloops at 664 : ...it is fair to say that the City of Kamloops had a statutory power to regulate construction bylaw. It did not have to do so. It was in its discretion whether to do so or not. It was, in other words, a «policy» decision. However, not only did it make the policy decision in favour of regulating construction by-law, it also imposed on the city's building inspector a duty to enforce the provisions of the by-law. This would be Lord Wilberforce's «operational» duty.

The Court concluded that the operational level of the decision regarding enforcement established a duty of care to the homeowners. Further, the municipality was liable for negligence because its failure to enforce the by-law did not stem from a policy decision given that no policy decision had been made.

24. [1989] 1 S.C.R. 705, (1989), 94 N.R. 1, 45 M.P.L.R. 1, [1990] I.L.R. 9[93,049, 23 Q.A.C. 1, 15 A.C.W.S. (3d) 95.

25. Supra, note 5 . 
large boulder tumbled from the wooded slope above the highway onto their vehicle. The plaintiff was severely injured and his daughter was killed. The plaintiff alleged negligence on the part of the government for failing to properly maintain the highway. The trial judge found that the system of inspection and the manner in which it was carried out was in the «policy» sphere and thus not a matter for judicial review. The British Columbia Court of Appeal dismissed the appeal.

In considering the matter, Cory J. turned to the two step test outlined in Anns by Lord Wilberforce. Speaking for the majority ${ }^{26}$ he stated ${ }^{27}$ :

«Even with the duty of care established, it is necessary to explore two aspects in order to determine whether liability may be imposed upon the respondent. First, the applicable legislation must be reviewed to see if it imposes any obligation upon the respondent to maintain its highways or, alternatively, if it provides an exemption from liability for failure to so maintain them. Secondly, it must be determined whether the province is exempted from liability on the grounds that the system of inspections, including their quantity and quality, constituted a "policy" decision of a government agency and was thus exempt from liability.»

While acknowledging that the line between «policy» and «operational» decisions was difficult to determine, the court said that it was essential that it was done. Justice Mason of the Australian High Court provided guidelines in Sutherland Shire Council v. Heyman ${ }^{28}$ which Cory J. found «to be most helpful» ${ }^{29}$ :

«...the dividing line between them [policy and operational factors] will be observed if we recognize that a public authority is under no duty of care in relation to decisions which involve or are dictated by financial, economic, social or political factors or constraints. Thus

\footnotetext{
26. Dickson C.J.C. and Wilson, La Forest, L'Heureux-Dubé, Gonthier, JJ. concurred. Sopinka J. dissented.

27. Supra, note 5, at 1236.

28. (1985), 60 A.L.R. 1., (1985) 157 C.L.R. 424.

29. Supra, note 5 at 1242.
} 
budgetary allocations and the constraints which they entail in terms of allocation of resources cannot be made the subject of a duty of care.» (original emphasis)

Notwithstanding a greater invitation to see government action as subject to the call on public resources and political vagaries, Cory J. refused to see this action in Just as policy ${ }^{30}$ :

«... the public authorities had settled on a plan which called upon it to inspect all slopes visually and then conduct further inspections of those slopes where the taking of additional safety measures was warranted. Those matters are all part and parcel of what Mason J. described as "the product of administrative direction, expert or professional opinion, technical standards or general standards of care." They were not decisions that could be designated as policy decisions.»

As such, the system of highway inspection was found to be in the operational sphere and, accordingly, it was held that a private law duty of care resulted. Not only was the system of inspection required to be reasonable but there was an onus for reasonableness in the manner in which the inspections were carried out. The case was remitted for trial on the negligence issues ${ }^{31}$.

By contrast, Sopinka J. agreed with the lower courts. He said ${ }^{32}$ :

«... In my opinion, the conclusion of the trial judge (1985), 64 B.C.L.R. 349, and a unanimous Court of Appeal (1986), 10 B.C.L.R. (2d) 223, was the correct one. This conclusion is expressed by Hinkson J.A., speaking for the court affirming the following passage from the reasons of McLachlin J. (now of this Court) :

30. Ibid., at 1246 .

31. At 1246 : At trial the conclusion was reached that the number and frequency of inspections, of scaling and other remedial measures were matters of policy; as a result no findings of fact were made on the issues bearing on the standard of care. Since the matter was one of operation the respondent was not immune from suit and the negligence issue had to be canvassed in its entirety. The appellant was therefore entitled to a finding of fact on these questions and a new trial should be directed to accomplish this.

32. Ibid., at 1247-48. 
...I conclude that the decisions here complained of fall within the area of policy and cannot be reviewed by this court. The number and quality of inspections as well as the frequency of scaling and other remedial measures were matters of planning and policy involving the utility of scarce resources and the balancing of needs and priorities throughout the province. Decisions of that nature are for the government authorities, not the courts ${ }^{33}$.»

The judicial split in Just and the roles of shifting political will and budgetary imperatives demonstrate the overall uncertainty, if not precariousness, of this approach.

\section{BROWN v. BRITISH COLUMBIA}

In Brown, the plaintiff was injured early in November, 1985 on a Friday morning when he lost control of the vehicle he was driving on a patch of black ice on the highway and went over an embankment. The Department of Highways was still on its summer schedule which ${ }^{34}$ :

33. Sopinka J. at 1251-52 also found support in earlier decisions : The extent of the liability of a municipality in British Columbia was settled by Barratt v. District of North Vancouver, [1980] 2 S.C.R. 418. While a municipality has the authority to maintain highways, it has no duty to do so. What it does in this respect is within its statutory discretion.

$\cdots$

My colleague's reasons are based essentially on an attack on the policy of the respondent with respect to the extent and manner of the inspection program. In my opinion, absent evidence that a policy was adopted for some ulterior motive and not for a municipal purpose, it is not open to a litigant to attack it, nor is it appropriate for a court to pass upon it. As stated by Lord du Parcq in Kent v. East Suffolk Rivers Catchment Board [1940] 1 K.B. 319, at p. 338 :

...it must be remembered that when Parliament has left it to a public authority to decide which of its powers it shall exercise, and when and to what extent it shall exercise them, there would be some inconvenience in submitting to the subsequent decision of a jury, or judge of fact, the question whether the authority had acted reasonably, a question involving the consideration of matters of policy and sometimes the striking of a just balance between the rival claims of efficiency and thrift.

This statement was approved by Lord Wilberforce in Anns...

34. Supra, note 6, at 6 . 
«...was operated by four men working for one long shift from $7: 00$ a.m. to 4 :20 p.m. from Monday through Thursday. There was as well a call-out system for emergencies which might occur during the remainder of the week.»

Brown alleged that the accident and resultant injuries were the result of negligence on the part of the Department of Highways in how it scheduled the sanding crew as well as the manner in which the sanding was carried out under that schedule ${ }^{35}$. The trial judge found that the system of dispatch was a policy matter as was the maintenance of the road «which excluded any duty of care with respect to the injury received by $\mathrm{Mr}$. Brown ${ }^{36}$.

The British Columbia Court of Appeal found that it had not been established at trial that there had been any failure on the part of the employees or if there was one that it was a contributing cause of the accident. The court held that the decisions about staffing were not proved to be irrational nor was it shown that the Crown and its employees failed to meet the standard of care imposed upon $\mathrm{it}^{37}$.

To determine if a duty of care existed, the court examined the applicable legislation and found that there was no statutory exemption from liability contained within the Highway Act ${ }^{38}$, nor section 8 of the Occupiers Liability $A c t^{39}$, nor section 3(2)(f) of the Crown Proceeding Act ${ }^{40}$. Finding that there was no exemption, Cory J., for the majority ${ }^{41}$, then turned to the policy versus

35. Ibid., at p. 7. The Trial Division had two allegations of negligence on the part of the Crown placed before it : ...failing to respond in a timely fashion to the reports of icy conditions and to remedy them, ...(and) failing to maintain the section of the road where the accident occurred so that ice would not form on it.

36. (1989), 17 M.V.R. (2d) 69.

$37 . \quad$ (1992), 65 B.C.L.R. (2d) 232, [1992] 3 W.W.R. 629, 10 C.C.L.T. (2d) 188, 37 M.V.R. (2d) 70, 10 B.C.A.C. 303,21 W.A.C. 303.

38. R.S.B.C. 1979 , c. 167.

39. R.S.B.C. 1979 , c. 303.

40. R.S.B.C. 1979 , c. 86.

41. Gonthier, Iacobucci and Major JJ., concurring. Actually, all seven judges agreed on the result. La Forest and McLachlin JJ. agreed with Cory J.'s reasons, «Subject to the comments expressed in Swinamer». Sopinka J. came to the same conclusion as Cory J. but for different reasons. 
operations issue in the system of schedules for the sanding $\mathrm{crew}^{42}$, and adopted the following dictum from $J u s t^{43}$ :

«True policy decisions involve social, political and economic factors. In such decisions, the authority attempts to strike a balance between efficiency and thrift, in the context of planning and predetermining the boundaries of its undertakings and of their actual performance. True policy decisions will usually be dictated by financial, economic, social and political factors or constraints.

The operational area is concerned with the practical implementation of the formulated policies, it mainly covers the performance or carrying out of a policy. Operational decisions will usually be made on the basis of administrative direction, expert or professional opinion, technical standards or general standards of reasonableness.»

Cory, J. viewed the decision of the department to maintain a summer schedule for the duration that it did, as one of policy ${ }^{44}$ :

«... involving classic policy considerations of financial resources, personnel and significant negotiations with government unions. It was truly a governmental decision involving social, political and economic factors.»

Such a decision is not reviewable by the courts. Neither was there an allegation that the decision was not bona fide or outside of the area of a proper exercise of discretion; the court, therefore, was not required to turn its attention to those matters. Additionally, the allegations of negligence in the manner of the call-out system did not prove to be material to the matter at hand. Accordingly, the appeal was dismissed.

Justice Sopinka, in a judgment that agreed with the disposition favoured

42. Supra, note 6, at 15 . The court noticed that there had been no allegation «... that the decision was not made in good faith or that it was patently unreasonable. There was therefore no need to consider these questions.»

43. Ibid., at pp. 15-16.

44. Ibid., at 16 . 
by the other judges, did not concur in the approach taken. As he observed in Barratt, in Brown there is no statutory duty to maintain the highways, only the power to do so. Justice Sopinka also took issue with the reliance on the policy versus operational spheres in the determination of a duty of care. In support of this position he referred to the growing body of academic literature ${ }^{45}$ which is critical of the «policy/operational» line of reasoning as the basis of determining liability for public authorities.

\section{SWINAMER v. NOVA SCOTIA}

In Swinamer, the plaintiff was also involved in an accident while driving his vehicle. In this instance however, a tree from private property adjacent to the roadway fell on his truck. He was severely injured. He alleged that the Transportation Department was negligent in its duty to take reasonable steps to maintain the highway in such a manner so as to prevent accidents. The Department's responsibilities were described as follows ${ }^{46}$ :

«As part of the ordinary maintenance activities of the Department, fallen trees and branches were removed usually after storms. The Department as well, removed trees which had been identified as hazards either by the members of the public or Department personnel. These were invariably obviously dead trees, with branches that could fall on the highway.»

In 1983, in response to complaints from the public about dead trees along the side of the roads, the engineer responsible for this roadway conducted a study of the damaged trees in the area. His intent was to quantify the problem in order to secure sufficient budgetary funds to address the issue as he did not

45. See D. COHEN and J.C. SMITH, «Entitlement and the Body Politic : Rethinking Negligence in Public Law» (1986) 64 Can. Bar Rev. 1; M.K. WOODALL, «Private Law Liability of Public Authorities for Negligent Inspection and Regulation» (1992) 37 McGill L.J. 83; J.A. SMILLIE, «Liability of Public Authorities for Negligence» (1985) 23 U.W.O.L. Rev. 213; S.H. BAILEY and M.J. BOWMAN, «The Policy/Operational Dichotomy -- A Cuckoo in the Nest», [1986] Cambridge L.J. 430; L.N. KLAR, «The Supreme Court of Canada : Extending the Tort Liability of Public Authorities» (1990) 28 Alta. L.Rev. 648; P.M. PERELL, «Negligence Claims against Public Authorities» (1994) 16 Advocates' Q. 48. 
have the necessary funds to remove all of the trees at the time.

At trial, the Department was found liable, based on its negligence in conducting the inspection of the trees ${ }^{47}$. The Nova Scotia Court of Appeal ${ }^{48}$ reversed the lower court's decision and dismissed the claim for the following reasons $^{49}$ :

«(1) $\quad$ there is no statutory duty requiring the Minister to maintain provincial highways;

(2) there is no liability imposed on an abutting owner for a nuisance on an adjoining property;

(3) there is no statutory power to enter onto lands abutting the highway to inspect or remove trees;

(4) any duty at common law to repair highways does not extend to adjoining lands;

(5) even assuming a duty to remove dangerous trees from lands abutting a highway, there was no evidence that the tree in question constituted a danger prior to the accident;

(6) the finding by the trial judge that there was a policy to inspect and remove diseased trees from adjoining lands which was the key to his decision, was not supported by the evidence.»

The Supreme Court of Canada, in reviewing the legislation for an exemption from liability, noted section 5 of the Public Highways Act $t^{50}$ :

«5. The Minister may construct or maintain any highway, or may on behalf of Her Majesty in right of the Province enter into contract or agreements for such construction or maintenance, but nothing in this Act compels or obliges the Minister to construct or maintain any

47. (1991), 101 N.S.R. (2d) 333, 275 A.P.R. 333, 6 C.C.L.T. (2d) 270.

48. (1992), 108 N.S.R. (2d) 254, 294 A.P.R. 254, 10 C.C.L.T. (2d) 207, 35 M.V.R. (2d) 191.

49. Ibid., at 265 (N.S.R.).

50. R.S.N.S. 1989, c. 371. 
highway or to expend money on any highway.» (emphasis added)

The court opined that the emphasized wording was not specific enough to either provide immunity or preclude liability. It turned to Anns for reference to the significance of public duty once a statutory power had been exercised ${ }^{51}$.

«The author observes ${ }^{52}$...that prior to Anns ..., public authorities "were excused because their statutory power did not create a legal duty to come to the plaintiff's assistance". This concept was successfully challenged in Anns for although "the defendant was under no public duty, ... the statutory power conferred on it for the health and safety of the public engendered a private duty, once having decided to exercise that power, to carry it out with due care."» (original emphasis)

The court also dealt with issues raised by the respondent relating to the differences between the Nova Scotia and British Columbia statutes, the latter which the respondent asserted protected the Crown against liability. He argued that the Nova Scotia legislation «... provides that the province is only liable for a tort committed by its officers or agents, if that tortious act of the servant or agent would, in itself, have given rise to a cause of action ${ }^{53}$. The British Columbia legislation, (the jurisdiction in which Just was decided), provides that the Crown is liable to the same extent as a person of full age and capacity without restriction or limitation to tort liability. Cory J. dismissed this $\operatorname{argument}^{54}$ :

«Obviously the Crown can only be liable as a result of the tortious acts committed by its servants or agents since it can only act through its servants or agents. Let us assume, for the purposes of resolving this issue, that the actions complained of by the appellant were indeed negligent. That is to say the failure of the Crown to rely on trained personnel to inspect the trees and the failure of those persons or this personnel to identify the tree in question as a hazard constituted

51. Supra, note 7, at 27.

52. J.G. FLEMING, The Law of Torts, 8th ed., Sydney, Law Book Co., 1992 at 155.

53. Supra, note 7, at 28.

54. Ibid. 
negligence. Yet those very actions or failure to act were those of the Crown's servants undertaken in the course of the performance of their work. If those were indeed acts of negligence then the Crown would be liable. The arguments of the Crown are regressive and to accept them would severely restrict the ability of injured persons to claim against the Crown.»

The court then turned its attention to the respondent's claim that the Department of Transportation had no authority to enter the lands adjoining the highway to remedy a dangerous situation. This proposition was also rejected ${ }^{55}$.

Having examined the issue of the duty of care through the statutory provisions, and dealt with the respondent's arguments, the court proceeded to the crucial issue of the nature of the decision - policy versus operational. In contrast to the facts in Just where a policy existed to inspect the rock slopes for potentially dangerous rocks, the matter before the Supreme Court within Swinamer contained no such «policy» to inspect for dangerous trees. A survey had been undertaken to identify potentially dangerous trees in order that the extent of the problem might be known and funds applied for to deal with the issue, but this did not yet represent a policy. Cory J. noted ${ }^{56}$ :

«The trial judge, in his reasons, reviewed the Department's decision to conduct a survey with the object of ascertaining whether it constituted a policy decision which would exempt the respondent from the duty to remove the tree which caused the accident. This is not the correct approach. The enquiry should not be aimed at determining whether a policy decision has been made which specifically exempts a governmental authority from tort liability. Rather, it should be directed at determining what decisions constituted policy and were thus exempt from tort liability and what decisions or actions were

55. Cory J. relied on section 4 of the Public Highways Act which states : 4 . The Minister has the supervision, management and control of the highways and of all matters relating thereto. The judge said that this gave the Minister broad powers with respect to the highways and went on to say, at 29 : It is rather bizarre to think that the Department of Transportation could leave a very old, very large dead tree leaning precariously over the highway without taking steps to remedy the situation, simply because it was located just outside the highway right-of-way.

56. Ibid., at 30 . 
operational and thus could, if negligent, attract liability.»

The court found that the survey represented a «preliminary step in the policy making process». Further evidence by the engineer as to the allocation of funds to possibly deal with the matter reinforced the finding that this was a policy matter and therefore outside the scope of review by the courts.

A final issue pertained to the question of negligence in the actions of the Department insofar as the conduct of the survey. On balance the court found no negligence «demonstrated in the operational aspects of carrying out the policy decision» ${ }^{57}$.

Cory J. stated, for the majority, that the court could not agree with the first four conclusions of the Court of Appeal. However, as in the Brown decision, the Supreme Court dismissed the action on the basis of a finding of a policy decision which the court held to be outside of its jurisdiction to review. Also similar to the Brown case, the allegations of negligence (in the manner of the survey of dead trees or trees that represented a hazard) were not supported by the court's review of the facts. Accordingly, the appeal was dismissed ${ }^{58}$.

\section{ANALYSIS AND CONCLUSION}

The early law on negligence liability of public authorities was set out in East Suffolk, which was decided prior to the enactment of the Crown Proceedings Act in the United Kingdom. There it was held that public

57. Ibid., at 32 .

58. Madame Justice McLachlin agreed with the conclusion of Cory J. but, like Sopinka J. in Brown, found an alternative basis for her decision. Having participated on the Court of Appeal in Brown, she was not a part of the Supreme Court of Canada considering that case, but one could divine her perspective. She would have gone further in Swinamer. From her reading of Anns, McLachlin J. found that a policy decision to do something and then exercised at the operational level in a negligent manner gives rise to a private law duty of care. In the case at hand, a policy decision to do something has not been made therefore there is no corresponding duty. Barratt is also authority for this approach. In that case, Martland J., at 585, was of the view : ... that the determination of the method by which the Municipality decided to exercise its power to maintain the highway, including its inspection system, was a matter of policy or planning, and that, absent negligence in the actual operational performance of that plan, the appellant's claim fails. 
authorities had absolute immunity from civil liability for discretionary decisions. The Anns decision represented a radical departure from the notion that the electorate carried the sole responsibility to judge the decisions and actions of elected officials by use of their franchise, and instead tried to define a basis on which public authorities would be liable. As noted by Lord Wilberforce in his examination of the statutory position of the council in $A n n s^{59}$ :

«It is no accident that the [Public Health Act] is drafted in terms of functions and powers rather than in terms of positive duty. As was well said, public authorities have to strike a balance between the claims of efficiency and thrift (du Parcq L.J. in East Suffolk) : whether they get the balance right can only be decided through the ballot box, not in the courts.»

The court's consideration of a method by which public authorities could be judged led to the adoption of the conceptual distinction between «policy» and «operational» decisions ${ }^{60}$. Based on earlier decisions of other jurisdictions, policy matters considered in a bona fide manner were held to provide no exposure to civil liability. Actions and decisions taken within the operational sphere would be subject to the ordinary principles of negligence.

It had been suggested in Just $t^{61}$ that the expansion of the public sector into almost all facets of daily life led to the need to examine the extent to which principles of private law liability should realistically apply to public authorities. Anns represents the foundation of the policy or operations diadic framework as it is still applied in Canadian courts. These two most recent cases from the Supreme Court of Canada, Brown and Swinamer, add no new insights to the policy versus operations distinction. In fact they may be criticized for further confusing and destabilizing it.

59. Supra, note 2 at 754 (A.C.), 501 (All E.R.). du Parcq L.J.'s comments from Kent v. East Suffolk can be found in [1939] 4 All E.R. 174 at 184, [1940] 1 K.B. 319 at 338.

60. For a thorough discussion of the common law see : L.A. REYNOLDS and D. A. HICKS, supra, note 8; M. Kevin WOODALL, «Private Law Liability of Public Authorities for Negligent Inspection and Regulation», (1992) 37 McGill L.J. 83; Lewis N. KLAR, «The Supreme Court of Canada : Extending the Tort Liability of Public Authorities», (1990) 28 Alta L. Rev. 648.

61. Supra, note 5, at 1239. 
What we do learn from Brown and Swinamer is the commitment of the Supreme Court of Canada to stay the course with the principles and indeterminate approach that were ushered in with Anns and which have been so widely and consistently criticized. This is so even in light of evidence that the House of Lords ${ }^{62}$ and other Commonwealth jurisdictions ${ }^{63}$ are retreating from Anns. While it is unfortunate that they offer no assistance to more clearly delineate or define those matters which fall within the policy sphere and those which are plainly in the operations sphere, these decisions are nonetheless significant in signalling the Supreme Court's adherence to the model, at least until they can find or fashion something finer.

Consider an example of the uneven, if not capricious, application of the principle. Cory J. for the majority in Just held that «the manner and quality of an inspection system is clearly part of the operational aspect of government activity» ${ }^{64}$. Matters of policy which are characterized by factors such as budgetary considerations or personnel limitations were not sufficient in Just to clothe the province with immunity as to its system of inspection of rocks along highways. Nevertheless, in Brown the court found that the summer schedule was a policy decision.

In Swinamer, meanwhile, the Department of Transportation decision to undertake a survey of dangerous trees was held to be «...a preliminary step in what will become a policy decision involving the expenditure and allocation of funds ${ }^{65}$. A survey considered to be preliminary to a policy decision had all the

62. See, eg., the House of Lords decision in Murphy v. Brentwood District Council [1991] 1 A.C. 398, [1990] 2 All E.R. 908. It restricted the liability of the public authority to situations of pure economic loss.

63. The leading case on governmental liability in tort in Australia is The Council of the Shire of Sutherland v. Heyman, supra, note 28, found that policy versus operations is not a general test for government liability in tort and is applicable only to situations where the public authority made a decision not to act. In New Zealand, the Privy Council found in Takaro Properties v. Rowling [1987] 2 N.Z.L.R. 700 (P.C.) that the distinction «... does not provide a touchstone of liability.» Thus it would appear that while the Canadian courts are moving in the direction of expanding the tort liability of the Crown through critical examination of policy and operational matters of government, jurisdictions throughout the Commonwealth are abandoning the distinction for other than the most specific of applications.

64. Supra, note 5, at 1245.

65. Supra, note 7, at 30. 
appearances of a system of inspection. In what way is the survey of dead and potentially dangerous trees different from the inspection of the rock work crew whose job it was to identify loose or dangerous rocks? In both circumstances the workers failed to identify the source of the ultimate tragedy. If a decision which is «preliminary to a policy decision» provides immunity to the public authority, at what point would a decision which is «pre-operational» cross over from policy to operations?

The notion of budgetary constraint and political motive guiding the determination is also circular. Ultimately, every decision and action by government is reducible to economic considerations. Why would the law consider that public authorities are immune to budgets and fiscal accountability much in the same way as private organizations? The same applies to political motivation. Every official action, inaction and utterance can be ultimately attributed to political objective as it can be attributed to non-political purposes. The court is not equipped to accurately surmise, if it can be done at all, and balance the political content of the conduct of public authorities.

The effect of these seemingly irreconcilable judicial decisions is an inexorable enlargement of the scope of civil liability. This may be seen as inescapable given the range of activities in which government is involved. The effect nevertheless has been to confer an abiding sense of chance in the distinction between policy and operational matters.

The frustrating lack of judicial unity continued with the Brown and Swinamer decisions. In Just, the three levels of court had six judges finding the decision to be operational, while five judges found them to be grounded in policy. In Brown and Swinamer, divergent conclusions were not a major problem at the Supreme Court of Canada but the court was split on both the use of the policy versus operations approach, what it means and the manner in which the determination is reached. Yet it is this framework which structures the application of duty of care which, in turn, ultimately leads to the conclusion about liability. Characterizing the «either/or» result along these lines, where everything rests upon the all-or-nothing conclusion, is like pulling a rabbit out of the hat. Injured people can always be expected to look for compensation to the deep pocket of government. It is of course the taxpayers who will pay for the negligence of Crown agents. What is there, moreover, to prevent this 
particular issue from being decided upon the judge's view of the degree of compassionate grounds for recovery?

Some commentators have called for Crown liability to accord more closely to the private law duty of care ${ }^{66}$. Any immunity is thought to promote negligence, or at least countenance it, and reduce public accountability. These proponents would likely be content with the trend to expand the scope of liability. After all, what difference should it make to a plaintiff if he or she was injured from private or public neglect ${ }^{67}$. The injury is equally grievous in both cases. On the other hand, the law must permit the Government to govern in the public interest without concern for adverse consequences that might be visited upon each particular individual. To hold that its decisions of a policy nature would be subject to review by the courts would pitch the entire system of government and administration into a quagmire, likely to be bogged down by a flood of claims given the enormous expanse of activities in which various levels of government are involved each day. This concern received attention by Wilson J. in Kamloops from the perspective that any finding of a duty of care comparable to that of the private individual carried with it the risk of opening the «floodgates and creat(ing) an open season on municipalities» ${ }^{68}$. Moreover, the claims are likely to be greeted with woolly, but nevertheless demanding, standards of public performance which would exceed the prescriptions of conduct for private defendants. The public authority could always have done more to avoid the accident.

It could be argued that every decision of a public authority could be characterized as a policy decision while every action could be held to be operational. Or, that every activity of government contains within it policy as

66. See, eg., P. W. HOGG, Liability of the Crown, supra, note 19 at Preface, iv and 139-40. As Director of the project of the Ontario Law Reform Commission on the Liability of the Crown, Professor Hogg's opinion is also contained within the Report on The Liability of the Crown, 1989, supra, note 13.

67. One is reminded of the words of Aristotle, from Nicomachean Ethics, circa 340 B.C. in this context :

It makes no difference whether a good man has defrauded a bad man or a bad man defrauded a good man, or whether a good or bad man has committed adultery : the law can look only to the amount of damage done. (emphasis added). 
well as operational elements which co-exist on a continuum. While this may be a satisfactory circumstance for some, it remains as ambiguous as the current analysis ${ }^{69}$.

This approach has been defended as offering as much definition as can be brought to the issues. This is the view of the Ontario Law Reform Commission $^{70}$ :

«In our view, the common law of torts has been reasonably successful in developing and adapting tort principles in ways that are appropriate to public sector activity by the Crown. For example, the operational/planning distinction in torts accommodates, in what we regard as a generally satisfactory manner, the essential policy-making role of government, while imposing a reasonable duty of care on the Crown and its servants in their day-to-day activities.»

The suggestion of numerous academic writers following the Just decision that the scope for policy decisions would be severely restricted while the operational sphere would be enhanced has not been borne out by these most recent decisions. Policy decisions continue to be characterized by an expenditure of funds, budgetary constraints, personnel limitations - «decisions involving social, political and economic factors.» There was no distinction in the Brown and Swinamer cases as to the level of the decision making which had previously been raised as a determining factor in Just.

Given the decision of the Court not to seize the opportunity presented by Brown and Swinamer to chart a new direction in the area of liability for public authorities, the examination of alternatives and scholarly dissertations might just as well be set aside for now. The court could scarcely send a clearer

69. Cf. HOGG supra, note 19 , at 139 :

To be sure, the planning-operational distinction is merely one of degree, and the existence and definition of the common law duty of care remain imprecise. But similar comments could be made about the negligence doctrines that are applicable to private activity.

70. See, Report on The Liability of the Crown, Ontario Law Reform Commission, 1989, supra, note 13, at 24. 
signal that its course is set on hold ${ }^{71}$. One observes that the personal injury suffered in most of the recent Canadian cases arose from motor vehicle accidents on public roadways. This often produces a seriously injured plaintiff, whom compassion can favour heavily, in comparison to the inert and virtually infinite juridical person of the Crown. The law applying to public authorities must be certain not to develop by proxy as the law of motor vehicle mishaps on public property.

Efforts nevertheless should be directed toward refining and modelling the delineations which are decisive to the analysis. In this regard, Professor Hogg's thoughts are apposite ${ }^{72}$ :

«The merit of the word "planning" is that it implies decision-making of a generality and complexity that can plausibly be contrasted with the "operational" level of decision-making. Decision-making at the planning level depends upon a range of policy considerations that a court cannot be expected to evaluate, let alone replicate. This is the reason for immunity : the question whether a planning decision has been made negligently is a question that is not suitable for judicial resolution.»

In the meantime, legislative bodies which still find themselves dissatisfied with the extent of civil liability flowing from the decisions of public authorities continue to grip the ultimate lever of public policy : the power to enact legislation itself. They might consider enactment of protective exemptions where public authorities are engaged, to foreclose the issue. Keeping in mind

71. This threshold determination is related to the issue of public interest standing. The fact that the Supreme Court of Canada is recently showing a tendency to restrict public interest recourse, on the grounds of scarce judicial resources and the need for a concrete factual background, may explain its reluctance to enlarge the scope of public authority liability for negligence. See, eg. Canadian Council of Churches v. Canada (Minister of Employment and Immigration) [1992] 1 S.C.R. 236, (1992), 88 D.L.R. (4th) 193, 132 N.R. 241 and $H y$ and Zel's Inc. et al. v. Ontario (Attorney General) and Paul Magder Furs Ltd. et al. v. Ontario (Attorney General), (1994) 107 D.L.R. (4th) 634 (S.C.C.). But cf. Conseil du Patronat v. Quebec (Attorney General) [1991] 3 S.C.R. 685, 87 D.L.R. (4th) 287.

72. «Taking the Government to Court : Advanced Issues in Public Law», Continuing Legal Education Seminar, the Continuing Legal Education Society of British Columbia. Held in Vancouver, British Columbia, February 16, 1990. at 4.1.02. 
(1994) 24 R.D.U.S.

Crowning glory:

liability in negligence

of public authorities revisited

Cory J.'s comments from Swinamer relative to the duties and the powers of the Minister contained in the Public Highways Act, legislative drafters are cautioned to capture a «clear statutory exemption». 